UNITED STATES

DEPARTILENT OF THE INTERTOR

GEOLOGICAL SURVEI

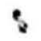

Translation No. 37

OBSERVATION OF A "FRONT" OF REGIONAL METAMORPHISM

by

René Perrin and Marcel Roubault

Translated by Mrs. Séverine Britt .

U. S. GEOLOG ICAL SURVEY
OPEN F I LE REPORT
$54-32$
THIS REPORT IS PRELIMINARY AND HAS NOT
WEEN EDITEO OR REVIEWED FOR CONFORMITY
NOMENCLATURE.

Washington

1953 


\section{OBSERVATION OF A "FRONT" OF KLEGIONAL METAMORPHISM}

PERRIN, René and ROUBAULT, Marcel, Observation d'un "front" de métamorphisme régional: Bullevin de la Société Géologique de France, ser. 5, v. 11, p. 183-193, 5 figs., 2 plates, 1941.

Translated by Mrs, Séverine H. Britt, U. S. Geological Survey, 1953.

Drawing his inspiration from the theories on metamorphism by reaction in the solid state, and from some observations, : Kẹné Perrin/in his.article

- Perrin, René, Le métamorphisme générateur de plissenent, Annales des Hines, Paris, October 2935.

"Metanorphism, the generator of folding" stated in 1935:

1) that some "sudden arrest" of regional metamompisn may occur and that some formations may present a barrier to its progress. It seemed to him that the Trias effertively played that role in some parts of the Alps (Perrin, René, p. 14 and 15 ).

2) p. 33 "A sedimentary formation overlying a folded crystalline rock in disconformity with the schistosity of the latter, does not prove that this rock (the crystalline) was formed and folded prior to the deposition of the sediment." Finally, he advised one (p. 32), before drawing any definite conclusion from the absence of contact metamorphism, to observe very closely the modifications either of the crystalline rock, or of the 
sedimentary formation, or of both in the vicinity of the contact, any modification being an indication of metanorphic action.

Because these concepts seemed at first extremely bold, the authors made a thorough study of some specific cases.

The present article is concerned with the west contact of the crystalline schist of the Beaufortin Massif, located between the Arly and the Isere Valleys, with a conglomerate formation composed of pink quartz pebbles of various sizes in a sandstone groundmass._/ This conglonerate,

- The general geologic study of that area was made by E. Ritter: Ia Bordure Sud-Ouest du Mont Blanc (Les plis couchés du Mont Joly et de ses attaches), Bull. Carte Geol. Fr., no. 60, tome IX, April, 1897).

very easy to recognize, is especially well exposed at Flumet, Mollières d'Ugine, Venthon, in the Arly Valley. E. Ritter correlated it with the Trias, at Fumet; at Hollières d'Ugine, there are two layers of conglomerate separated by a layer without pebbles. René Perrin, in the previously mentioned paper, has expressed the hypothesis that the conglom. erate of schist pebbles in a schist matrix, assigned to the Carboniferous, was the result of the metamorphism of this quartzose conglomerate. The authors also intend to consider this hypothesis.

However, one thing is certain: these layers, as a whole, are perfectly concordant with the overlying Mesozoic formations; on the other hand, there is a striking similarity with the Triassic arkose which so commonly overlies the crystalline rocks in the so-called autochthonous massifs in the Swiss and French Alps.

At first sight, this conglomerate appears in numerous areas to be a purely sedimentary formation not affected by metamorphism, and lying 
above the subjacent crystalline schist, whose metamorphism distinctly appears to have taken place at an earlier time. At Flumet, there is a very distinct angular unconformity between the schistosity of the crystalline schist and the bedding of the conglomerate strata. At Mollieres and Venthon, there is, on the contrary, more general concordance with some local unconformities.

As for the crystalline schist, it is part of the Beaufortin schist, and can be seen for tens of kilometers; this is, no doubt, what is referred to as comprehensive regional metamorphism.

The authors' attention was first drawn by a visible contact at the Venthon aluminur. factory. At first one gets a fairly clear impression that the visible thin slice of conglomerate is fncluded in the crystalline schist, because if the schistosity of the upper part of the schist of the section were projected, it would overlie the conglomerate (fig. I).

But, if the conglomerate is studied closely, it seems, to the naked eye, in some places to be entirely unmetamorphosed; in some other places that are close to the contact, pebbles are included in a matrix of metamorphic and schistose character, and in the space of a few centimeters there is a progressive change to crystalline schist in which a few pink quartz pebbles are embedded. The impression is immediately gained that the metamorphism of the schist had reached the conglomerate, partly invaded it, and, if the following expression can be used - which gives a good mental picture - it died out within the distance of a few centimeters.

This observation incited the authors to look more closely at the Molliéres d'Ugine contact, where it is exposed and accessible on both sides of the ArIy, and also to examine the talus blocks from this contact. 
At first, a large and particularly interesting block (about $70 \mathrm{~cm}$ long) was observed and collected. It is shown on fig. 2 , it broke off nearly along the contact of the green schist and the pinkish conglomerate, but fortunately a thickness of a few centimeters of schist remained and It can be seen that pink pebbles and even areas of conglomerate are entirely enclosed in the schist. The schistosity of the latter 1s, as a whole, concordant with the contact, but at one place a "tongue" of light green schist, clearly discordant, penetrates the conglomerate at an angle and engulfs the pebbles.

At a second point, a bright.green stretch a few millimeters thick, very similar in appearance to the schist, branches from the schist and joins it again approximately $15 \mathrm{~cm}$ farther.on, :nclosing a plate of conglomerate of normal appearance, thus outlining a veritable amall weflon"]

I The word nfilon" (vein) is used here to express an appearance and not a strict meaning.

(vein) of schist (fig. 3).

Pursuing their research in other areas, the authors noted that:

1) In the conglomerate adjacent to the contact, close observation revealed numerous small separated areas of greenish color and schistose appearance;

2) At some points, in the space of a few centimeters at most, a progressive change could be observed from schist to conglomerate that is not at all metamorphic in appearance;

3) At other points, within the conglomerate, a network of very thin filaments of green mica was found, which was similar to that in the schist (pl. IV, photo 3). 
The following observations were made on samples collected by the authors:

1) From one sample to another, a continuous incre s of metamorphism with parallel development of the schistosity resulting In a real crystalline schist with pink quartz pebble inclusions.

2) Clear samples of apophyses with very sharp contacts, or "filons" (veins), of crystalline schist crossing the conglomerate and aleo including pink quartz pebbles (fig. 4 and 5, plate IV, photo 1 ).

To end the macroscopic description, it will be added that at Molliēres d'Ugine, between two beds of conglomerate, there is a bed of lustrous greenish rocks, more metamorphic in appearance to the naked eye than the enclosing conglomerate.

Observations in the field were supplemented by the microscopic analysis of thin sections.

This detailed study was concerned essentially with a series of rocks from the strata assigned to the Trias, near the bridge over the Arly, at Molliēres d'Ugine.

A) White quartz sandstone, very slightly greenish in places, with a few ferruginous spots visible to the naked eye.

As a whole, clearly sedimentary in appearance with quartz grains rounded and generally convex. In places, however, some of the quartz grains show more complex forms with concave and convex sinuosities giving the impression of peninsulas separating intermediate gulfs. The matrix is very finely crystalline and includes a high proportion of thin phyllitic flakes that cannot be identifed with assurance except that a few at least are of muscovite and chlorite. Ferruginous traces aigzag between the grains. 
B) Sandstone, almost white, very similar to A.

General appoarance similar to the preceding sarmple with quartz grains embodied in the phyllitic matrix; in some places, the shapes of the quartz grains are very complex giving strongly contorted aspects that recall some of the "corrosion" forms which were described in a previous article by the authors_(Photo 4, plate IV, and 4, pl. V).

/ Perrin, R. and Roubault, M., Le granite et les réactions a l'état solide, Bull. Serv. Carte Géol. Algérie, 5e série, no. 4, 1939.

C) Greenish white conglomerate. In places, very irregular grains. Tendency to some schistosity with appearance of greenish, satiny, foliated plates visible to the naked eye.

A thin section of the conglomerate shows two different zones, which for convenience will be designated 1 and 2 .

Zone 1 , of very fine grain, is made up almost exclusively of quartz as tiny interlocking grains. In places, there are sinuous zones with parallel edges; having the appearance of veins in which the quartz grains are larger and more elongated normal to the direction of the vein, the general appearance being very similar to that described for sample $\mathrm{E}$ (Photo 5, pl. V).

Zone 2 is composed of quartz grains commonly very sinuous in form in a matrix containing very thin micaceous flakes, and very similar in appearance to that of sample B. The boundary between zone 1 and 2 is indistinct; a quartz grain situated on tinis boundary shows, toward zone 1, a sinuous shape with well marked "gulfs" and "peninsulas". 
D) Rock close to C. Conglomerate with fine and fairly uniform texture, with tendency to some schistosity as shown by satiny greenish zones.

Numerous quartz grains embodied in a phyllitic groundmass; the quartz grains have regular shapes. Some large grains appear as amygdaloidal nodules included in wavy streaks or lenses of mica, the general texture resembling that of an augen-gneiss.

E) Rock with very fine texture, schistose, micaceous. In the mass, greenish-gray color. In thin section, the texture is that of a mica schist grading into chlorite schist. Bands of chlorite and of sericite alternate regularly with bands of quartz (Photo $5, \mathrm{pl}$. IV).

Two samples cut in this rock showed the presence of bands of quartz with parallel edges, perpendicular to the schistosity and having the appearance of veins (Photos 1, 2, 3, pl. V).

In reality, these bands are composed of quartz grains elongated normal to the length of the vein and parallel with the schistosity. Moreover, these quartz grains frequently grade into quartz grains of the normal schist bands._ A few apatite crystals.

\footnotetext{
_ Without referring again to the use of the word "filon" [vein] and the necessary distinction between the true and false veins, the appearance here described and shown in photomicrographs seems to be that of a particularly distinct false vein.
}

F) G) H) Conglomerate and quartzite.

Appearance similar to samples $A$ and $B$. The only difference is the aspect of quartz grains which frequently are strongly indented, and have sinuolis shape. 
The examination of these thin sections gives the following general impression: the texture of the sandstone and conglomerate is not as simple as appears to the naked eye. Many of the quartz grains do not have the distinct shape of the grains of an unaffected sandstone: the common appearance of "corrosion" forms, the sinuous and complex forms, the nature of the matrix itself - of variable texture - are very distinct signs of an incipient metamorphism and of recrystallization. Finally, the greenish and schistose zones (sample E, "tongues" and "veins" of the blocks shown by figs. 2, 3, 4, and 5) have the texture and composition of true chlorite schist or sericite schist absolutely similar to schists of the great metanorpnic series.

- After this sumnary of detailed observations, the conclusions of the authors are given below:

1) A close examination of the contacts, which to $i$, naked eye appear to represent sinple deposition of a congiomerate on an "old schist", reveals a much more complex phenomenon and shows that the conglomerate superposed on the crystalline schist has also been metamorphosed. And, considering the sinilarity of tlo minerais and the very short distance between the non-metamorphic conglomerate and the crystalline schist, it seems obvious that the metamorphism of the two rocks was contemporary. Consequently, the recommendation at the beginning of this article "to carefully observe the contacts before coming to the conclusion of a simple deposition and age difference" appears well-founded. 
2) Although the metamorphism has also affected the conglomerate, and was undoubtedly subsequent to the deposition of the latter, the schistosity is in places completely discordant with the stratification: tongues or apophyses (figs. 2, 3, 4).

Therefore it seems justified to repeat / that the discordant rela-

\section{René Perrin, loc. cit.}

tion of the crystalline schist does not prove, by itself, the earlier age of this schist in its present state, contrary to present opinions. The use of discordant relationship in tectonics and in stratigraphy, as that of pebiles in a conglomerate, has a value only if one of the formations (in discordant relationship) or the matrix (in conglomerate) is completely unmetamorphosed.

3) Observations have shown a certain continuity of regional metamorphism inasmuch as an incipient metamorphism is found in parts of the conglomerate which appear intact; however, in some places a real discontinuity is seen by the naked eye as well as under the microscope; and in some other places a progressive change within, at the very most a few centimeters, is seen from a completely metamorphosed rock to a rock where metamorphism is barely evident. This discontinuity occurs either at the base of the conglomerate itself, or within it.

The authors' conclusion, extraordinary as it may seem, is that in this particular instance, a sudden arrest of the regional metamorphism took place, and that a real "front" of regional metamorphism exists, according to the expression used by Wegmann for migmatization, which moreover makes the word "regional" lose its significance._ 
The authors propose an hypothesis to explain this fact. It appears possible that the conglomerate, owing to a lack of coherence at the contacts, or for some other reason, has presented a real barrier to the progress of metamorphism, a barrier that was breached in some places but not in others. It will be noted, concerning regional metamorphism, that definite discontinuities substantiate the authors' theories of the propagation of metamorphism by reactions in the solid state - which necessitates close contact - much more than by solution, gas, filtration columns, etc., which are not conpatible with such discontinuities.

The possibility of a sudden arrest of regional metamorphism is considered to be fundamental because of its effects on tectonics; very detailed studies rather than rapid examination are required to allow wellfounded conclusions which would lead to contrary conclusions in the present instance.

4) It is also necessary to draw attention to the analogy which exists in detail between the features of the schist front as observed and the features of the so-called "eruptive" front of some granitic masses: exomorphism, inclusions, apophyses, veins or networks of small veins. With the exception of the scale the phenomena are alike._

The difference in scale could be explained by differences of temperatures prevailing at the time of the alteration, because the reaction speeds increase considerably with the temperature.

The "front" of metamorphism of the crystalline schist has, in the present case, behaved similarly to that of granitoid "eruptive" rocks._ 
The word "eruptive" commonly used to designate the granular crystalline rocks, whose formation has been very slow, seems incorrect; it is thought that the expression "eruptive rocks" ought to be restricted to the volcanic rocks unquestionably formed by eruption in the precise meaning of the term in the expression "volcanic eruption." In the authors' opinion, the former expression of "igneous rocks" seems more correct to designate the granular, microgranular and microlithic rocks as a whole. For thj.s reason the word "eruptive" was put in quotation.

This behavior is characteristic - for the granites that E. Raguin calls "in circumscribed massifs" / - without, however, being universal. 7

Raguin, E., Problēmes de la géologie du granit: Revue des questions scientifiques, Louvain, Main 1937.

In a recent study on Greenland, / Wegmann indicated that a clearly 7

Owing to the present circumstances it has not been possible to give the exact reference.

"diffuse" granite of migmatitic origin had, however, an "eruptive" behavior in some respects in relation to the country rock.

This fact has also been observed for gneiss. M. J. Durand mentioned it some time ago for gneiss of the Massif Central which, for that reason, he qualified as orthogneiss.

The contact observed by the authors shows this behavior occurs in crystalline schist that is attributed to regional metamorphism; it caunot be in this case a question of liquid intrusion. 
Thus similar phenomena result from the propagation of fronts of the various kinds of metamorphism, i.e. granitization, migmatization, and regionil metamorphism.

The behavior term "eruptive" appears only as a particular case of this propagation, more common and, no doubt, more pronounced in granitization, but hose mechanism is not different from the others. The complexity of the chemical changes and of diffusion, and the variety of the formations concerned, may and should lead to multiple variations. It can be verified by a detailed observation of the contact of a granite with a country rock and of the inclusions of the latter in granite. The . variations are very numerous for a single contact, and also within one and the same inclusion where clear "fronts" of alteration can be found._

This phenomenon is visible in photographs of samples published in the authors' pamphlet: Le granite et les réactions ã l'état solide. Loc. cit.

But, more and more, under the various conditions a uniform mechanism seems to take shape, and the finding of apophyses and veins of crystalline schist including quartz pebbles, which remained in place, does not mean that such phenomena necessarily imply injection of liquid.

5) Finally, a particular question concerning the Alpine tectonics will be reconsidered.

The Beaufortin crystalline schist, which belongs to the "autochthonous Massifs", is classified as Hercynian and even, by Ritter, as preHercynian. A clear, precise fact comes out of the authors' observations: the metamorphism which created this schist in its present state has reached layers which are generally classified as Triassic, and which, 
in any case, are perfectly concordant beneath the entire Mesozoic of the Aravis mountain range.

This special study seems to corroborate the doubt expressed in 1935 by René Perrin of the so-called Hercynian age of these rocks. It can even be said in this particular instance that there is no proof that the metamorphism, whose visible front of propagation stopped inside or at the edge of the conglomerate, is of Alpine age. If one agrees with the writers, and with an increasing number of other authors, that there is no distinct metamorphism without change of volume, consequently without folding, the probability appears, on the contrary, that this metamorphism is of Alpine age because all the Mesozoic strata are perfectly concordant above the terrain affected by the metamorphism.

The conjecture is a serious one because it again raises questions concerning dognas that are well accepted. The authors do not feel that they have the right to come to a conclusion, and they think that new observations are called for, which should be made with the new idea in mind that the propagation of metamorphism termed as regional may terminate abruptly or within a few centimeters owing to conditions difficult to observe with the naked eye.

\section{Bxplanations of figures 1 - 5}

1. Section of the conglomerate visible at Venthon.

2. Block formed of conglomerate except on the anterior face, made up of a plate of schist. F, schistose tongue penetrating the conglomerate. Length about 70 centimeters.

3. F, "filon" of schist engulfing a fragment of conglomerate B. 4. and 5. F, "filon" of schist with inclusions of pebbles, traversing a block of conglomerate. 


\section{Bxplanation of plates IV and V}

Plate IV

1. Triassic metamorphic conglomerate showing in one of its extremities a green chloritic zone ( $v$ ) with an apophysis (a) penetrating a sandstone area (c) which is less affected by the metamorphism (2/3 natural size).

2. Triassic metamorphosed conglomerate $(\mathrm{Gg})$ with a zone of mica schist (s); the boundary between the two is very sinuous. ( $4 / 5$ natural size).

3. Triassic metamorphosed conglomerate (c) with very thin "veinlets" of schist (s); F, small quartz "vein" similar to those shown by the microphotographs $1,2,3$ of plate V. (2/3 natural size).

4. Sample B (p. 6); quartz grains (Q) with very sinuous and indented outlines, within a matrix (c) of thin phyllitic flakes and fine quartz grains. Polarized light $\times 30$ (approx.).

5. Mica schist (p. 7): bands of quartz (Q), muscovite and sericite (m) chlorite (c). Natural light $\times 30$ (approx.).

\section{Plate V}

1. and 2. In the mica schist (5) of plate IV, "veinlet" of quartz (F) with quartz grains perpendicular to the two edges (Q) and extending in places into the quartz aligned in the schist. 1) Polarized light, 2) natural light $x 30$ (approx.).

3. Another view of "veinlet" with quartz grains parallel to each other and perpendicular to the edges. Polarized light $\times 30$ (approx.) 
4. An indented quartz grain $(Q)$ in the metamorphosed conglomerate shown on photo 4 , plate IV, greater magnification than indicated for plate IV, photo 4. Polarized light $\times 150$ (approx.).

5. Zore $I$ of section $C(p .6)$. Finely crystallized quartz in a very small "vein" F with crystals oriented perpendicularly to the edges. Polarized light $\times 30$ (approx.). 
Note de R. Perrin at M. Roubault

Bull. Soc. Céol. de France

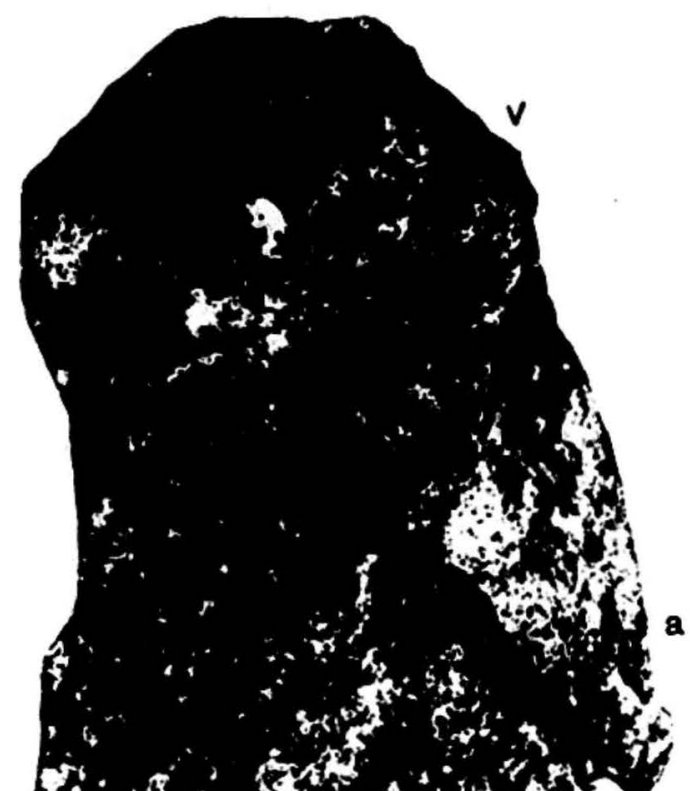

S. 6 : t. XI : pl. IV
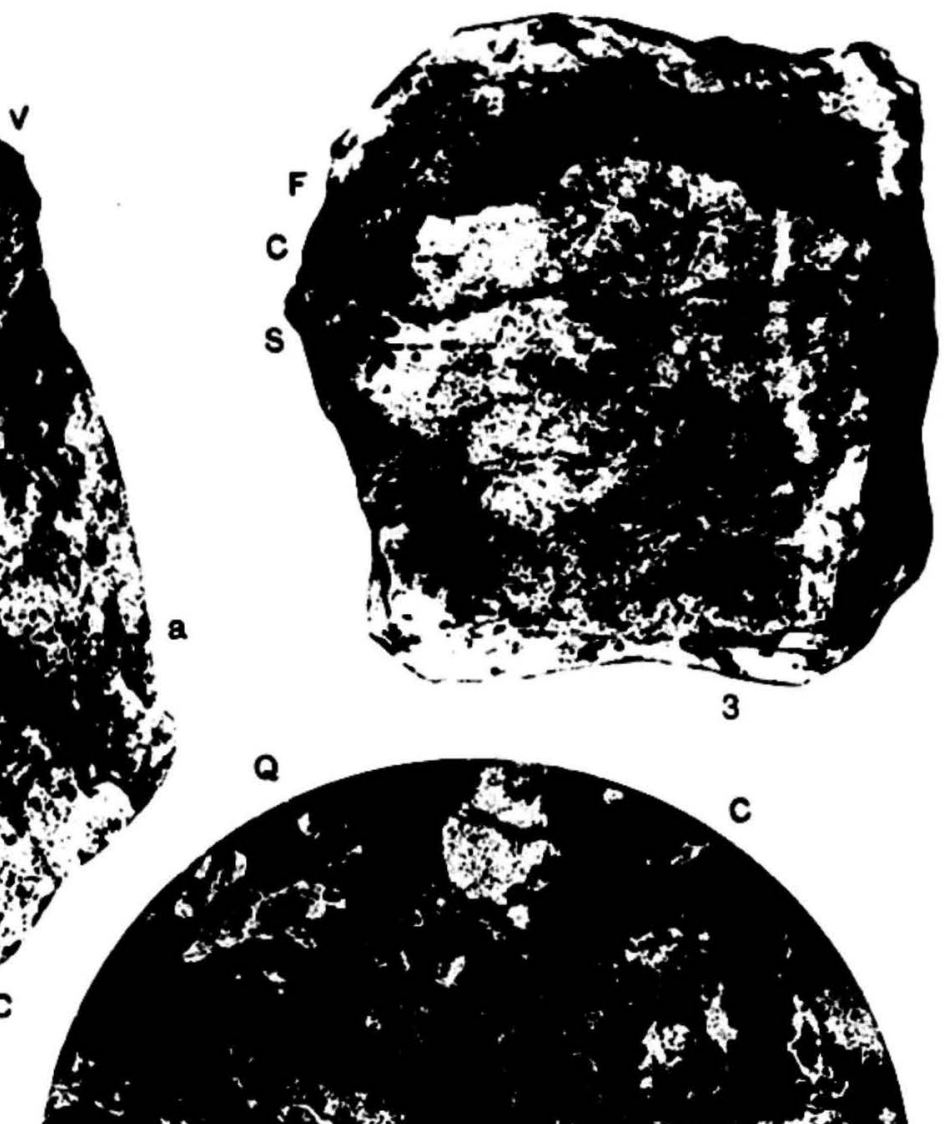

1

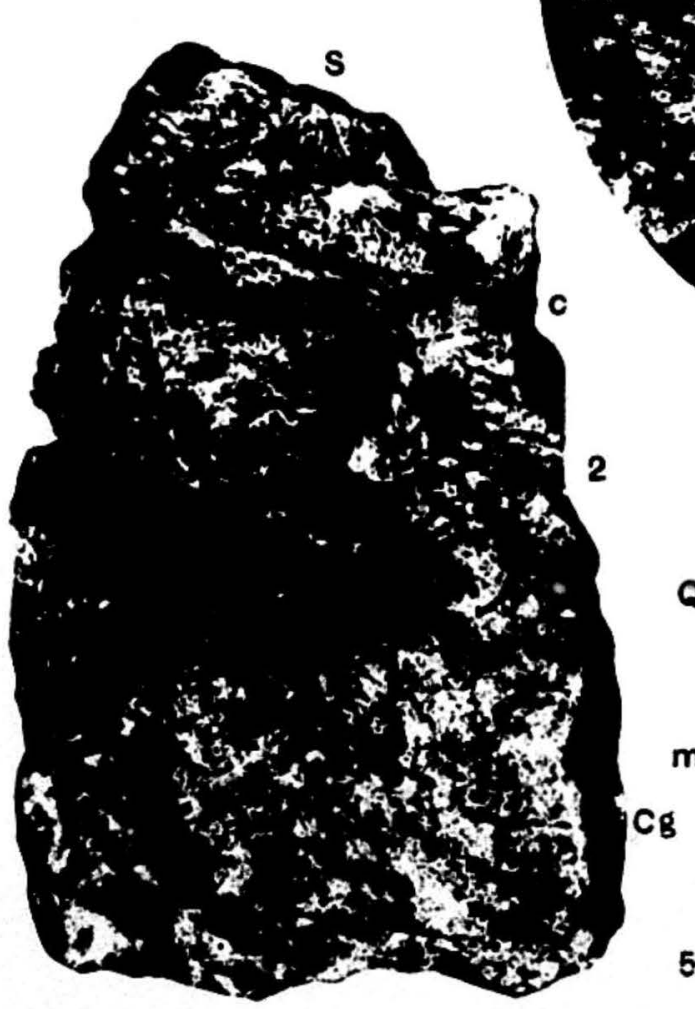

$m$ 2

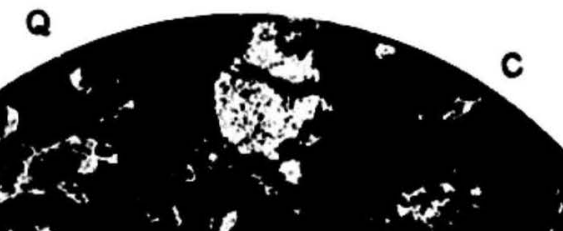

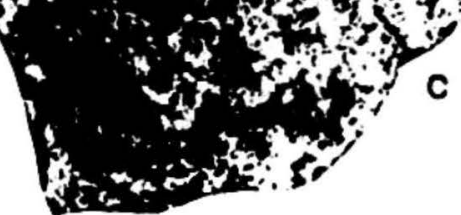

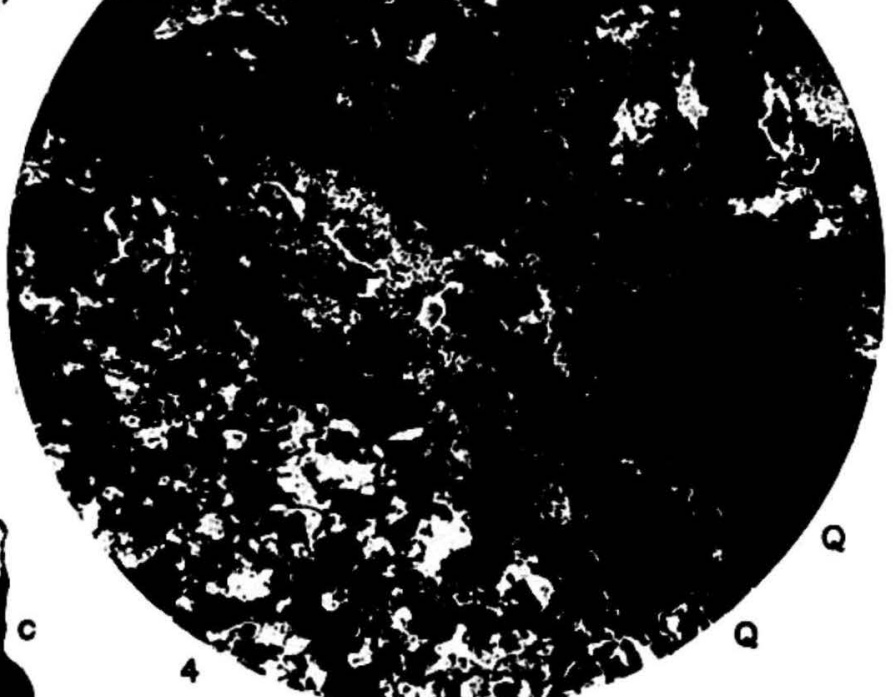

$\mathbf{Q}$

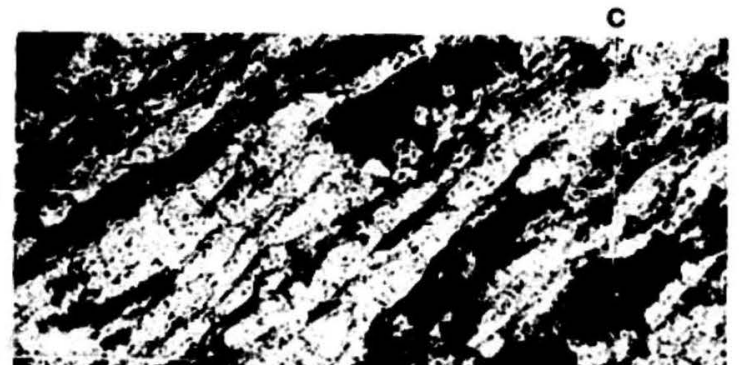

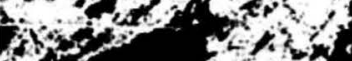

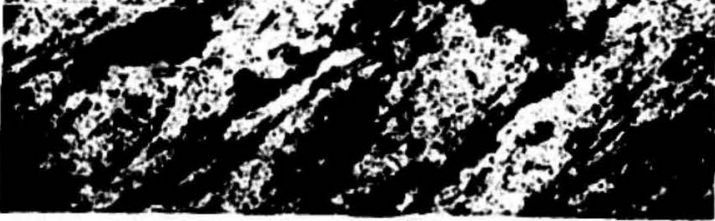

c1. M. Roubeult

Pnototypie Mémin. Arcueil (Seine) 

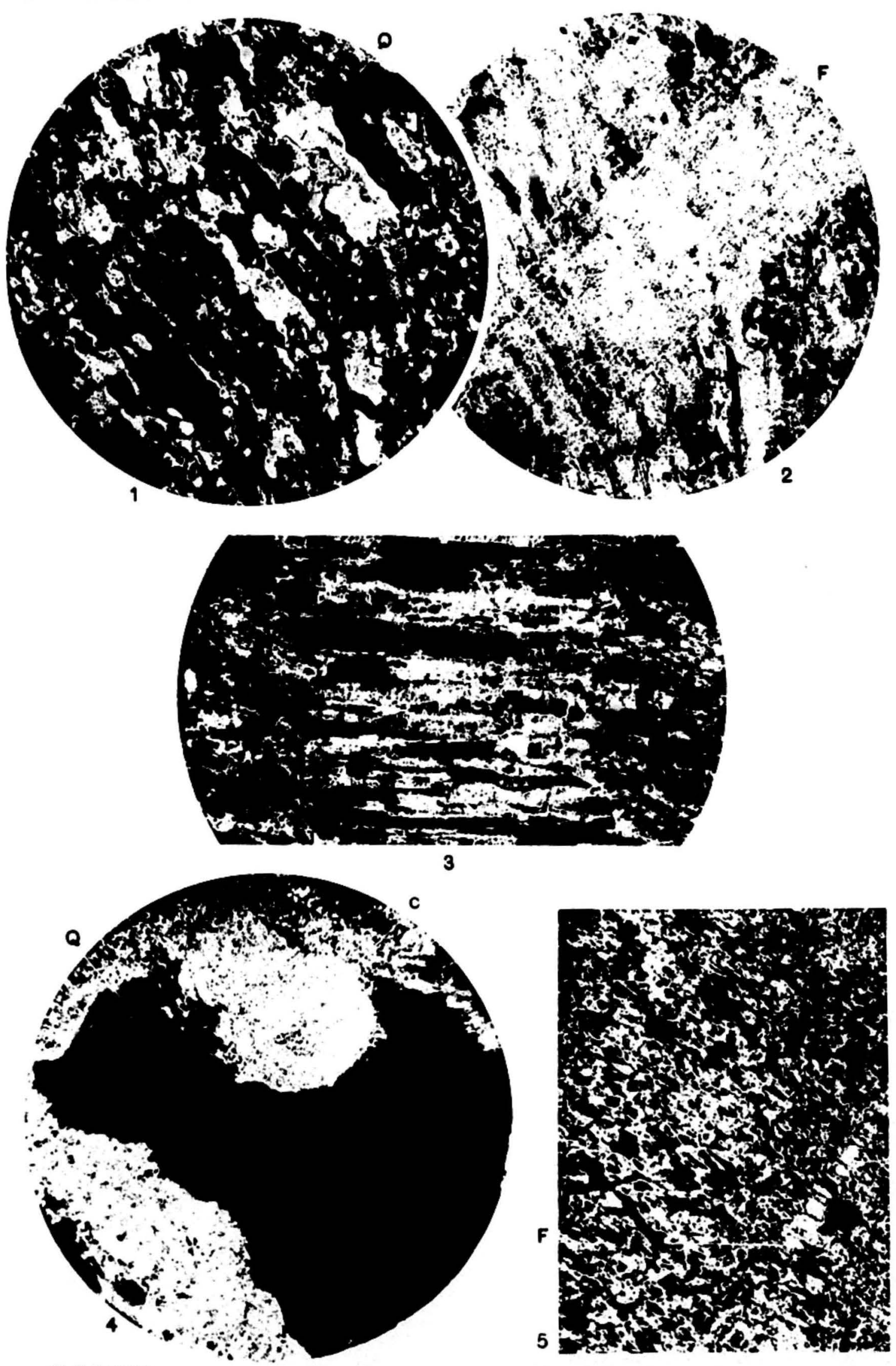


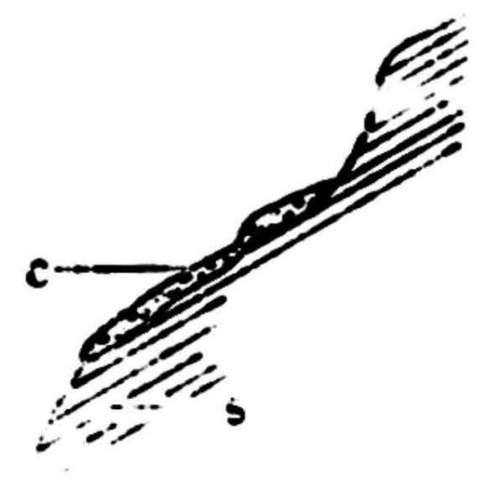

Frowe 1.

Section of the conplomente risibic at Venthon.

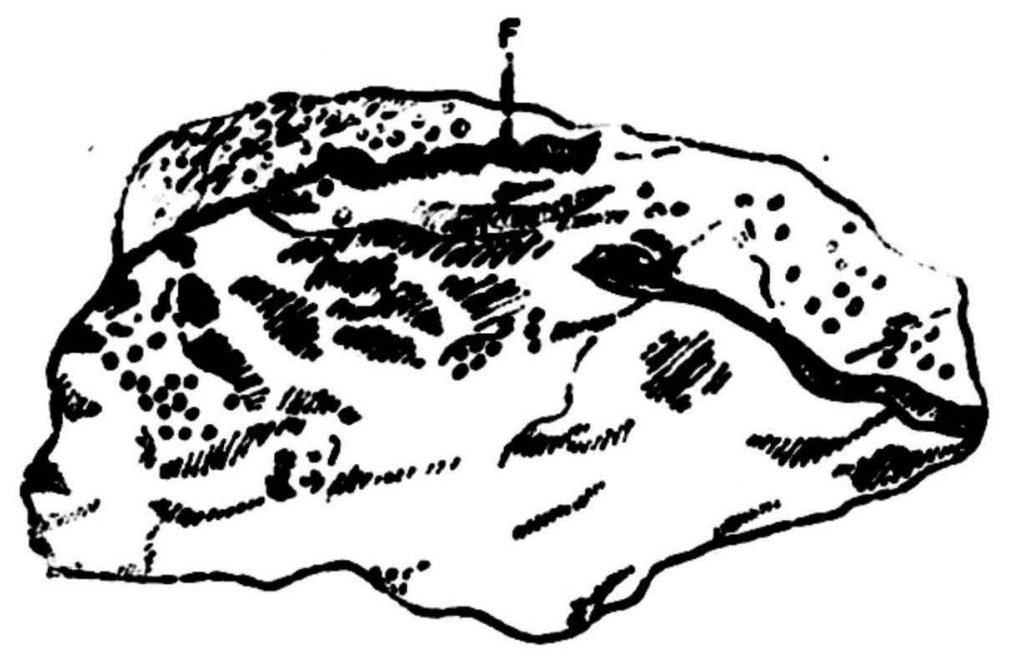

Plome 2.

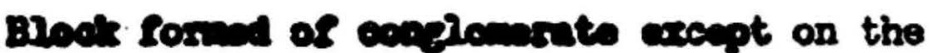
anterioc sace, ned up of a plate of endet. If cindotoss tongue peneterating tho ecoplomerate. Iongth about 70 eanternoters. 


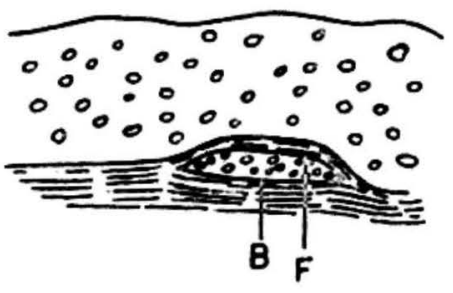

Figure 3. F, "filon" of schist engulfing a fragment of conflomerate $\mathrm{B}$.
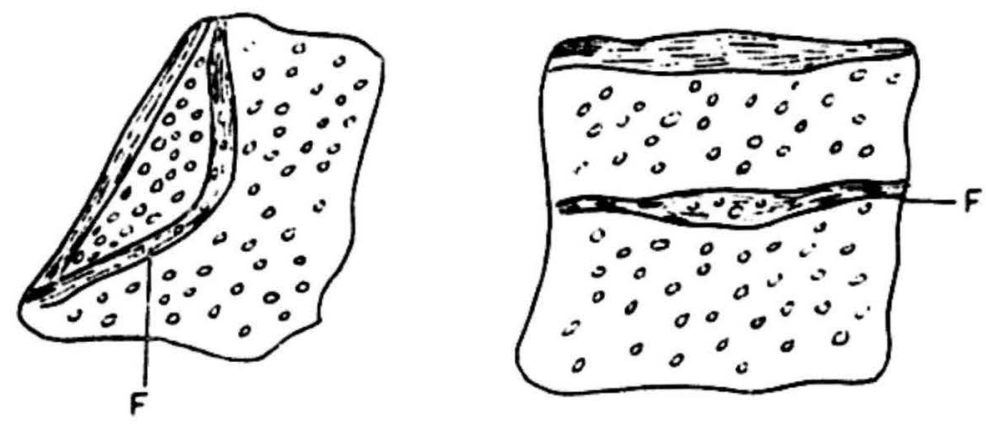

Figure 40 and 5, F, "fijon" of schist with iraclusions ai pebbles, traversin: a block of conglonerate. 